\author{
(c) (i) (8) \\ Jurnal Terapan Manajemen dan Bisnis is licensed under \\ A Creative Commons Attribution-NonCommercial 4.0 International License.
}

\title{
Determination of Performance Accountability of Local Government Organizations in Palembang
}

\author{
M.Thoyib(1), Indra Satriawan'2), Farida Husin' ${ }^{3)}$, Mega Asmarani ${ }^{4)}$, Periansya ${ }^{5)}$ \\ 1-5) Accounting Departement, State Polytechnic of Sriwijaya \\ E-mail: Thoyib1958@gmail.com
}

\begin{abstract}
In regional autonomy context, value for money is a bridge to deliver local government to achieve good governance. Value for money must be operated in local finance management and local budgeting. To support it, the management of public money with value for money concept, it needs regional budgeting and good local finance management. This research aims to set factors that influence performance accountability of local government organizations in Palembang. Factors that include are the influence of performance based budgeting and local financial accounting system to performance accountability as partial and simultant. This research using purposive sampling which part of nonprobability sampling of research instrument by 129 questionnaires that directly spread to 43 local government organizations in Palembang to the head of finance department revenue treasurer, and expenditure treasurer. Data of this research was analized by multiple regression using software SPSS 20.0. The result of this research show both as partial and simultanr performance based budgeting and local financial accounting system have positive influence and significant to performance accountability in local government organization
\end{abstract}

Keywords: Performance Based Bugeting, Local Financial Accounting System, Performance Accountability.

\section{Introduction}

This The condition of the budgeting system in the pre-financial reform era can not be separated from the impact of the economic crisis experienced by many Asian countries, including Indonesia that started from the economic crisis in Thailand. According to the Center for Indonesia Taxation Analysis (CITA, 2017) Since 2016, Indonesia's economic condition has improved and is predicted to increase in 2017, but it is still relatively slow and uncertain.

One of the efforts to realize increased revenues for development is to explore sources of funds originating from within the country, namely taxes. Tax is still the main source of State revenue. At the end of 2016, tax revenues reached Rp1,105.9 trillion or $81.6 \%$ of the target of Rp1,355.2 trillion (Darussalam). The data show that Indonesia's tax ratio is only about $12 \%$ in 2014, quite low when compared to the average tax ratio of 34\% (Akbar) OECD member countries.

Therefore, to optimize the potential revenue from tax sources in Indonesia the government issued several policy breakthroughs, one of which is tax amnesty or tax pardon 
with the policy is expected tax ratio to Gross Domestic Product (GDP) will increase to $14 \%$ in 2017.

Multidimensional (economic, monetary, legal and political) reform and crisis processes in Indonesia encourage the development of this paradigm, often called Good Governance. Good governance can be interpreted as an efficient public service, a reliable court system, a government accountable to the public.

Performance accountability supports the implementation of democratic governance so that people have a belief that the government can provide better public services through system reforms, programs, and government activities in serving the community to realize good governance performance towards good governance. Several factors affecting the performance accountability of the Local Government Organizations (SKPD) are performancebased budgets and regional financial accounting systems.

The implementation of the performance-based budget of the government hopes that the budget is used optimally to improve the welfare of the community, supporting the improvement of transparency and accountability of public sector management so as to influence the performance accountability of SKPD. Each SKPD must prepare the Financial Statement as possible. In preparing the financial statements is required transparency and accountability. Therefore, local financial accounting system plays an important role in the improvement of regional financial management so that local financial management can run properly. Regional financial accounting system functions to produce output in the form of financial statements that will be the basis for the assessment of the performance of the government itself and by parties concerned with local government (stakeholders of local government).

The paradigm of good governance encourages the reform of regional financial management which is marked by the issuance of Law no. 17 of 2003 on State Finances. One important keyword is the implementation of performance-based budgeting which is defined as a form of budget whose sources are linked to the outcome of the service.

The potential tax revenue from the ransom of tax amnesty funds will increase APBN revenue so that it will make the state budget more sustainable. With the increase of APBN since 2016 South Sumatera transformed into the best Province where the absorption of APBN in South Sumatera until 2018 which amounted to Rp 68 Triliyun (beritapagi). This large amount of budget will be very beneficial for the development in South Sumatra that will be felt directly by the community. Besides the increasing development budget in South Sumatera from APBN, the achievement of PAD of Palembang City has also exceeded the target (wartasumsel). Where PAD becomes a very important thing to run all the programs that have been prepared to provide the best service to the community both in terms of infastruktur, health, and education.

The current condition in the Government of Palembang City indicates that the Local Government Organizations (SKPD) is making a performance-based APBD to overcome budget constraints. Because the previous rules SKPD just enough to cut the budget without considering the level of interest program. To that end, SKPD needs to determine the program based on priority scale each year. The determination of priority programs has already been developed in the General Policy of Budget and Priority of the Provisional Budget Ceiling (KUA-PPAS). SKPD is also required to prepare the budget in detail in KUA-PPAS. Thus there will be no more mark-ups in the preparation of the budget.

After the Local Regulation (Perda) on organizational governance (nomenclature) was approved in 2016, the Government of Palembang City experienced many changes related to the budget and office assets to be used in the new SKPD nomenclature results, even though 
the municipal government (Pemkot) of Palembang has improved, There are still a few problems. This is related to the finances of several SKPDs, due to the enactment of nomenclature in 2016. There is a budget shortage in some SKPD amounting to Rp.58.9 billion. Where, from the nomenclature results submitted, Rp.118 billion was needed Rp.177 billion. There are several offices that are broken down or merged like, Department of Industry, Trade, and Cooperatives which initially became broken down into three departments namely Industry Service, Trade Service, and Cooperative and Small and Medium Enterprises (SMEs) with the existence so that the BPKAD must calculate Re-requirement in each SKPD. After the re-calculation of the Cooperative and Small and Medium Enterprises Office, it only requires $\mathrm{Rp} 2.8$ billion from the previously budgeted $\mathrm{Rp} 3.4$ billion, the Trade Office needs $\mathrm{Rp} 2.8$ billion from the initial budget while the need is $\mathrm{Rp} 2.4$ billion and the Industry Office Requires $\mathrm{Rp} 3.1$ billion from the initial budget of $\mathrm{Rp} 2.4$ billion. Therefore, a special budget shift for the SKPD that undergoes the change (tribunnews).

Other things are also experienced by the Office of Public Housing and Urban Settlements which experienced little problems in realizing street lighting due to errors in the use of the budget for public services (infopublik.id). Another SKPD that experienced problems is the Education Office of Palembang City that has not maximized the budget of each region for school improvement(laskarwongkito.com). From various problems experienced by some SKPD of Palembang City describes still not maximal implementation of performance based budget in SKPD of Palembang City to give best service to society.

The existence of regional financial management reform also brings renewal to the old system that has been used by the Regional Government both Provincial Government and District/City Government ie Manual Regional Financial Administration (MAKUDA) implemented since 1981 is no longer able to support the needs of Local Government. Local Government Accounting System (SAPD) is prepared so that the officers who perform the accounting function can understand and run the accounting process properly and correctly. If the application of local government accounting system is done correctly in presenting the financial statements, the accountability of the financial statements will be good as predetermined, indirectly also affects the performance accountability report of government agencies

After the occurrence of nomenclature in the city government (Pemkot) Palembang make some SKPD have to move office, this of course make some people who want to ask for service of society little disturbed, besides disruption of public service SKPD Kota Palembang also have little problem in process of recording, and changes in the classification and depreciation of the assets to be used SKPD, therefore the delay in submission of Local Government Financial Report (LKPD) Palembang to BPK in accordance with the specified time is 3 months after the end of the fiscal year ended and also the distribution of APBD Kota Palembang Can be disbursed to some SKPD Palembang, this is what makes some SKPD Palembang still can not provide optimal service to the community (tribunnews).

In the context of regional autonomy, value for money is a bridge to deliver Local Government to Good Governance. Value for money should be operated in the management of regional finances and local budgets. To support the implementation of public fund management based on the concept of value for money, it is necessary to have good local financial management system and local budget. A good Performance Based Budgeting by government agencies and optimal supervision on the quality of the government agency's financial report is expected to improve the performance accountability of government agencies so that the performance of government affairs can be optimized. 
Based on the introduction of the above problems can be seen that the Performance Based Budget and Regional Financial Accounting System becomes a determinant factor to support the implementation of Good Governance that can influence in improving Performance Accountability, for that the researcher is interested to examine about "Determination of Performance Accountability of Local Government Organizations in Palembang".

\section{Literature Review}

According to Halim and Kusufi (2014: 55) Performance-based budgeting is a publicsector budgeting technique designed to address weaknesses in traditional budgets, especially weaknesses caused by benchmarks that can be used to measure performance in achieving service objectives and targets public. The budget performance approach places great emphasis on the concept of value for money and the oversight of output performance.

Definition of Local Financial Accounting System itself is contained in the Minister of Home Affairs Decree no. Law No. 29 of 2002 on Guidelines for the Management, Accountability and Supervision of Regional Finance as well as the Procedures for the Formulation of Regional Revenue and Expenditure Budgets, the Implementation of Regional Financial Procedures and the Preparation of Regional Expenditure Budget Accounts which reads: "Local financial accounting system (SAKD) is an accounting system Which includes the process of recording, classifying, interpreting, summarizing transactions on financial events and financial reporting in the context of APBD implementation, carried out in accordance with accounting principles "(Article 70 paragraph 1).

According to Bastian (2010: 88) the term Accountability comes from the term English accountability which means accountability or circumstances to be accountable or circumstances to be held accountable. Performance accountability is one of the key words for good governance in the management of public organizations. The performance accountability of government agencies is regulated according to the State Administration Institution (LAN) Year 2008. Head of LAN Decree No.239 / IX / 6/8/2003 on Guidelines for Reporting Performance Accountability of Government Institutions, explains that the performance accountability of government agencies is the realization of the obligations of a government agency To account for the success and failure of the organization's mission in achieving the goals and objectives that have been established through the system of accountability periodically.

\section{Research Method}

This type of research according to the level of explanation is associative research with the type of data and quantitative analysis using the type of causality because in this study will be examined the causal relationship of independent variables (affecting variables) and the dependent variable (variables affected).

This research was conducted at the Local Government Organizations (SKPD) in Palembang. The place of study was chosen because it has all aspects of support for research to run well.

\section{Result of Research}

The entire document should be in Palatino Linotype font. Type 3 fonts must not be used. Other font types may be used if needed for special purposes. Recommended font sizes are listed below. 
This research was conducted by spreading the questionnaire to 153 respondents directly. Total questionnaires received by the researcher were 129 questionnaires, 18 questionnaires were not returned on the grounds that the respondents were not located and as many as 6 questionnaires could not be processed because there were several items of questions that were not filled in completely. Thus the number of questionnaires eligible for further analysis of 129 questionnaires

\section{Result of Valid Test}

Testing the validity of the instrument using statistical software, the value of validity is shown in the Corrected Item Total Correlation column. Based on the validity test it can be concluded that all question items to measure each of these research variables are declared valid. It can be seen that $r$-count is greater than $r$-table with $\mathrm{df} 30$ meaning $r$-table is 0,361

\section{Result of Realibility test}

Reliability test results for each dependent and independent variables show the value of $t$ arithmetic (Cronbach's Alpha)> 0.6 so that all items questionnaire research declared reliable and feasible used in data collection from respondents to test the research hypothesis. The alpha coefficient for Performance Accountability $(\mathrm{Y})$ variable is $0.860(>0.6)$. Performancebased budget (X1) of $0.894(>0.6)$ and Regional Financial Accounting System (X2) variables have alpha coefficient of $0.929(>0.6)$.

\section{Result of Normality Test}

Seeing the results of normality test can be used one-sample test Kolmogorov-Smirnov. In table 1 can be seen the value obtained $>0,05$ thus can be concluded the test results show residual normal distribution.

Table 1 normality test

One-Sample Kolmogorov-Smirnov Test

\begin{tabular}{|ll|r|}
\hline & & \multicolumn{1}{|c|}{ Unstandardized Residual } \\
\hline N & & 129 \\
Normal Parametersa,b & Mean & $0 \mathrm{E}-7$ \\
& Std. Deviation &, 23897597 \\
& Absolute &, 047 \\
Most Extreme Differences & Positive &, 036 \\
& Negative &,- 047 \\
Kolmogorov-Smirnov Z & &, 539 \\
Asymp. Sig. (2-tailed) & &, 933 \\
\hline
\end{tabular}

Source : proceeding SPSS 20

\section{Result of Multikolinearity Test}

Multicollinearity test results in this study can be seen in table 2 below:

Table 2 Multikolinearity test

\begin{tabular}{|ll|r|r|}
\hline \multirow{2}{*}{ Model } & \multicolumn{2}{|c|}{ Collinearity Statistics } \\
\cline { 3 - 4 } & (Constant) & & \multicolumn{2}{|c|}{ VIF } \\
\hline \multirow{4}{*}{1} & Anggaran Berbasis &, 658 & 1,519 \\
& Kinerja &, 658 & 1,519 \\
\hline
\end{tabular}

Source : proceeding SPSS 20 
Based on the above table, we can know the VIF value for each variable $<10$ and tolerance value $>0.10$. So it can be concluded that the regression model is free from the influence of multicolinearity

\section{Result of Heterokedastisity Test}

Detecting heteroscedasticity can see the scatterplot chart. As shown in Figure 2 below:

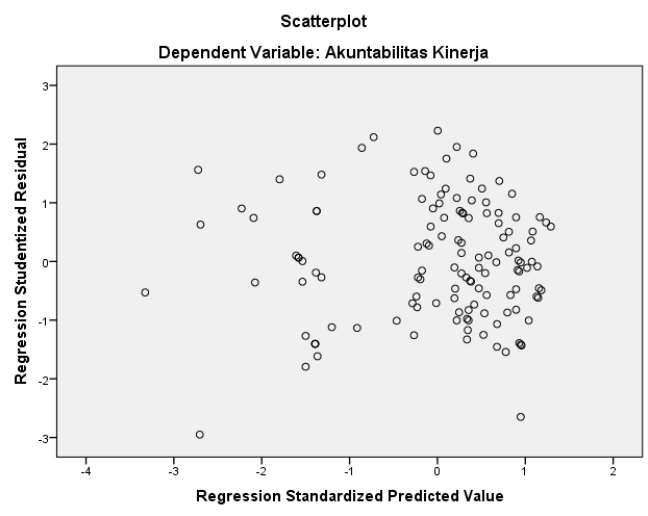

Figure 2 Diagram of Scatterplot Heterokedastisity Source : proceeding SPSS 20

In the picture above, there is no clear pattern because the spots spread above and below the number 0 on the $\mathrm{Y}$ axis, so it can be said that the regression model does not occur symptoms of heterokedastisitas.

\section{Result of Autocorrelation Test}

A good regression model is that there is no autocorrelation problem. Autocorrelation test in this research can be seen from table 3 below:

Table 3 Autocorrelation test

Model Summary ${ }^{b}$

\begin{tabular}{|l|r|r|r|r|r|}
\hline Model & \multicolumn{1}{|c|}{$\mathrm{R}$} & $\mathrm{R}$ Square & $\begin{array}{c}\text { Adjusted R } \\
\text { Square }\end{array}$ & $\begin{array}{c}\text { Std. Error of the } \\
\text { Estimate }\end{array}$ & Durbin-Watson \\
\hline 1 &, 786 &, 619 &, 612 &, 24076 & 1,772 \\
\hline
\end{tabular}

Source : proceeding SPSS 20

The Durbin-Watson yield is 1.772. While from DW table with significance 0.05 with amount of data $n=129$ and number of independent variable $\mathrm{k}=2$ yield dL value equal to 1.6812 and DU equal to 1.7441 , according to criterion DU $<$ DW $<4$-DU $(1.7441<1.772<2.2559)$, it can be concluded in this study there is no autocorrelation

\section{Multiple Linear Regression Analysis}

Multiple linear regression analysis is useful to analyze the linear relationship between two independent variables or more with one dependent variable. The hypothesis that is tested is Performance Based Budget and Regional Financial Accounting System have an effect on Performance Accountability.

Summary of hypothesis testing results can be seen in table 4 below: 
Table 4 Multiple Regression Test

\begin{tabular}{|c|c|c|c|c|}
\hline \multirow{2}{*}{\multicolumn{2}{|c|}{ Model }} & \multicolumn{2}{|c|}{$\begin{array}{c}\text { Unstandardized } \\
\text { Coefficients }\end{array}$} & \multirow{2}{*}{$\begin{array}{c}\text { Standardized } \\
\text { Coefficients }\end{array}$} \\
\hline & & B & Std. Error & \\
\hline \multirow{3}{*}{1} & (Constant) & 779 & ,262 & \\
\hline & $\begin{array}{l}\text { Anggaran Berbasis Kinerja } \\
(\mathrm{X} 1)\end{array}$ & 165 & ,062 & 181 \\
\hline & SAKD (X2) & ,657 & ,067 & 667 \\
\hline
\end{tabular}

Source : proceeding SPSS 20

Based on the above table, then obtained the resulting regression equation is:

$$
\mathrm{Y}=0.779+0.181 \mathrm{X} 1+0.667 \mathrm{X} 2+\mathrm{e}_{\mathrm{i}}
$$

(Sanusi, 2014:141)

\section{Test Results Coefficient of Determination}

Summary of test results coefficient of determination can be seen in table 5 below:

Table 5 Test Results Coefficient of Determination $\mathbf{R}^{2}$

Model Summary

\begin{tabular}{|l|r|r|r|r|}
\hline Model & \multicolumn{1}{|c|}{$\mathrm{R}$} & $\mathrm{R}$ Square & $\begin{array}{c}\text { Adjusted R } \\
\text { Square }\end{array}$ & $\begin{array}{c}\text { Std. Error of } \\
\text { the Estimate }\end{array}$ \\
\hline 1 &, $786^{\mathrm{a}}$ &, 619 &, 612 &, 24076 \\
\hline
\end{tabular}

Source : proceeding SPSS 20

The adjusted value of $\mathrm{R}^{2}$ is 0.612 , this means that $61.2 \%$ of the variation in performance accountability can be explained by the variation of the two independent variables of performance-based budgeting and the regional financial accounting system. While the rest $(100 \%-61.2 \%=38.8 \%)$ is explained by other causes outside the model

\section{t-Test (Partial)}

a t1-Test (Performance Based Budgeting (X1))

Table 6 t-test (Partial)

\begin{tabular}{|c|c|c|}
\hline Model & t & \multicolumn{1}{c|}{ Sig. } \\
\hline Anggaran Berbasis Kinerja (X1) & 2,665 &, 009 \\
\hline
\end{tabular}

Source : proceeding SPSS 20

Performance based budgeting variable has $\mathrm{p}$-value $0.009<0.05$ meaning significant, while $\mathrm{t}$ count $2.665>$ t-table 1,978 this means Ho refused, Ha accepted.

b. t2-Test (Local Financial Accounting System (X2))

Table 7 t-test (Partial)

\begin{tabular}{|l|r|r|}
\hline Model & $\mathrm{t}$ & \multicolumn{1}{|c|}{ Sig. } \\
\hline SAKD (X2) & & \\
\hline
\end{tabular}

Source : proceeding SPSS 20 
Local financial accounting system variables has p-value $0.000<0.05$ meaning significant, while t-count 9.835> t-table 1.978 this means Ho refused and Ha accepted.

\section{F-test (Simultan)}

To measure the influence of independent variables simultaneously/ together to the dependent variable can be seen from the analysis table 8 below:

Table 8 Simultan test (F test)

\begin{tabular}{|ll|r|c|}
\hline Model & F & Sig. \\
\hline 1 & $\begin{array}{l}\text { Regression } \\
\text { Residual } \\
\text { Total }\end{array}$ & 102,138 &, $000^{\mathrm{b}}$ \\
\hline
\end{tabular}

Source : proceeding SPSS 20

From the above table results can be obtained F-count $102.138>$ F-table 3.068 and $\mathrm{P}$ Value of $0.000<0.05$ which means independent variables together have a relationship with the dependent variable.

\section{Discussions}

\section{Relation of Performance Based Budgeting (X1) and Performance Accountability (Y)}

Based on the results of partial testing obtained value of Performance-Based Budget with t-count $2.665>$ t-table 1.978 with significance level $0.009<0.05$, thus Ho is rejected which means partially Performance Based Budgeting variables have a positive and significant effect on Performance Accountability of Local Government Organizations in Palembang, which means the better Performance Based Budgeting the better Performance Accountability of Local Government Organizations in Palembang.

This is supported also by the explanation of the results of descriptive statistical tests where the average majority of respondents by 81 people voted strongly agree with the average score percentage of respondents' responses on Performance-Based Budget of $62.8 \%$ (in the category strongly agree), which means Performance Based Budgeting has been assessed well by the Local Government Organizations (SKPD) in Palembang.

Based on the processing results of the questionnaire data showed that from 5 dimensions of Performance Based Budgeting variables are Performance Measurement, Awards and Punishment, Contract Performance, External and Internal Controls, and Management Accountability that has the most dominant value of Performance Measurement dimensions with the highest percentage value of $29.2 \%$ of the five dimensions of Performance Based Budgeting variables. This is in accordance with the results of this study where most respondents stated strongly agree to the statements on the questionnaire.

\section{Relation of Local Financial Accounting System (X2) and Performance Accountability (Y)}

Based on the partial test results obtained with the Local Financial Accounting System $9.835 \mathrm{t}$ count $>\mathrm{t}$-table 1.978 with a significance level of $0.000<0.05$, so that Ho is rejected, which means that in partial, Local Financial Accounting System have a positive and significant effect on the Performance Accountability of Local Government Organizations in Palembang, means the better Local Financial Accounting System the better performance Accountability of Local Government Organizations in Palembang.

This is supported also by an explanation of the results of descriptive statistical tests where the average majority of respondents is 102 people choose not agree with an average 
score of respondents about the percentage of the Local Financial Accounting System amounted to $79.1 \%$ (on a category strongly agree), which Means Regional Financial Accounting System has been assessed either by the Local Government Organizations (SKPD) in Palembang.

Based on the processing results of the questionnaire data showed that of the five dimensions variable Local Financial Accounting System Areas namely Procedures Accounting Cash Receipts, Procedures Accounting Accounts Payable, Procedures Accounting Fixed Assets / Regional Property, Procedures Accounting In addition to cash, and Presentation of Financial Statements which have a value most dominant the dimensions of Cash Receipts Accounting Procedure with an average value of 4.61 and has the highest percentage value of $21.7 \%$ from the fifth dimensions Local Financial Accounting System variables

Relation of Performance Based Budgeting (X1) and Local Financial Accounting System (X2) on Performance Accountability ( $Y$ )

Based on the test results simultaneously obtained F-count $>$ F-table that is $102.138>3.068$ with a significance level of $0.000<0.05$ so that Ho is rejected which means simultaneously or together variables Performance Based Budgeting and Local Financial Accounting System has a positive and significant effect on Performance Accountability of Local Government Organizations in Palembang, which means the better Performance Based Budgeting and Local Financial Accounting System, the better Performance Accountability of Local Government Organizations in Palembang. Based on the results of multiple linear regression testing also shows a constant value of 0.779 means that without the influence of Performance Based Budgeting and Local Financial Accounting System on Performance Accountability in Local Government Organizations in Palembang only 0.779.

The result of multiple linear regression test also showed that the influence of the improvement of Performance Based Budgeting to increase the Performance Accountability of SKPD in Palembang is 0.181 or $18.1 \%$ and the influence of the improvement of Local Financial Accounting System to increase Performance Accountability of SKPD in Palembang equal to 0.667 or $66.7 \%$ Of these results illustrate that the variables of Local Financial Accounting System gives the effect of the highest increase to the Performance Accountability of SKPD in Palembang.

\section{Conclusion}

Based on the partial test (t-test) shows that the variable of Performance Based Budgeting (X1) and Local Financial Accounting System (X2) have positive and significant influence to Performance Accountability ( $\mathrm{Y}$ ) of Local Government Organizations in Palembang means, if Performance Based Budget or Local Financial Accounting System increases then Performance Accountability will increase. While the simultaneous test results (Test-F) indicates that the independent variables together have a relationship with the dependent variable, meaning that Performance Based Budgeting (X1) and Local Financial Accounting System (X2) together influence on Performance Accountability Y) of Local Government Organizations in Palembang.

\section{References}

Afrina, Dina. (2015). "Pengaruh Penerapan Sistem Akuntansi Pemerintah Daerah, Pengendalian Intern, dan Sistem Pelaporan terhadap Akuntabilitas Kinerja Instansi Pemerintah". Jom FEKON. Vol.2. No.2. pp 1-15. 
Badan Pendidikan dan PelatihanKeuangan (BPPK). (2008). Pengukuran Kinerja, Suatu Tinjauan pada Instansi Pemerintah. Jakarta.

Bastian, Indra. (2009). Sistem Perencanaan dan Penganggaran Pemerintahan Daerah di Indonesia. Jakarta: Salemba Empat.

Darussalam, S.E.,Ak., CA., M.Si., LL.M Int. Tren, Outlook, dan Tantangan Pajak 2017

Fathia, Nurul. (2017). “Pengaruh Penerapan Sistem Akuntansi Pemerintah Daerah, Penerapan Anggaran Berbasis Kinerja, Kejelasan Sasaran Anggaran, Sistem Pelaporan Kinerja dan Pengendalian Akuntansi terhadap Akuntabilitas Kinerja Instansi Pemerintah (AKIP)". JOM Fekon. Vol.4. No.1. pp 670-685.

Ghozali, Imam. (2013). Aplikasi Analisis Multivariate dengan Program IBM SPSS 21. Semarang: Badan Penerbit Universitas Diponegoro.

Halim, Abdul dan Muhammad Syam Kusufi. (2014). Teori, Konsep, dan Aplikasi Akuntansi Sektor Publik. Jakarta: Salemba Empat.

Keputusan Kepala Lembaga Administrasi Negara Nomor 239/IX/6/2003 Tentang “Perbaikan Pedoman Penyusunan Laporan Akuntabilitas Kinerja Instansi Pemerintah".

Lembaga Administrasi Negara. (2008). Modul AKIP dan Pengukuran Kinerja. Jakarta: LANRI.

Lumenta, Agnestasia Laura. (2016). "Pengaruh Sistem Akuntansi Pemerintah Daerah dan Ketaatan Peraturan Perundangan terhadap Akuntabilitas Kinerja Instansi Pemerintah (Kabupaten Minahasa Selatan). Jurnal EMBA. Vol.4. No.3. pp 135-146.

Mardiasmo. (2009). Akuntansi Sektor Publik. Yogyakarta: ANDI.

Pendapat pribadi penulis oleh Dhoni Siamsyah Fadillah Akbar, pegawai Badan Kebijakan Fiskal Kementerian Keuangan RI. Tax Amnesty dan Momentum Reformasi.

Pusat Pendidikan dan Pelatihan Pengawasan Badan Pengawasan Keuangan dan Pembangunan (Pusdiklatwas BPKP). (2007). Akuntabilitas Instansi Pemerintah. Diklat Pembentukan Auditor Ahli. Edisi Kelima. 2007

Priyatno, Duwi. (2012). Cara Kilat Belajar Analisis Data dengan SPSS 20. Yogyakarta: ANDI.

Republik Indonesia. (2003). Undang-Undang No. 17 Tahun 2003 tentang Keuangan Negara. Lembaran Negara RI Tahun 2003, No. 4286. Sekretariat Negara. Jakarta.

Republik Indonesia. (2000). Peraturan Pemerintah No. 105 Tahun 2000 tentang Pengelolaan dan Pertanggungjawaban Keuangan Daerah. Lembaran Negara RI Tahun 2000, No. 202. Sekretariat Negara. Jakarta

Republik Indonesia. (2006). Peraturan Menteri dalam Negeri No. 13 Tahun 2006 Tentang Pedoman Pengelolaan Keuangan Daerah. Sekretariat Negara. Jakarta.

Republik Indonesia. (2014). Peraturan Presiden No. 29 Tahun 2014 Tentang Sistem Akuntabilitas Kinerja Instansi Pemerintah. Lembaran Negara RI Tahun 2014, No. 80. Sekretariat Negara: Jakarta.

Sanusi, Anwar. (2014). Metodologi Penelitian Bisnis. Jakarta: Salemba Empat.

Siaran Pers. (2017). Perpajakan 2017: Menjaga Momentum, Mencari Peluang. Jakarta.

Soraya, Gita, Rika, dan Cherrya. (2014). Pengaruh Anggaran Berbasis Kinerja dan Sistem Pelaporan Keuangan terhadap Akuntabilitas Kinerja pada Badan Pertanahan Nasional Wilayah Sumatera Selatan.eprints.mdp.ac.id/1475/1/Jurnal.pdf/ Diaksestanggal 5 November 2016.

Sugiyono. (2016). Metode Penelitian: Kuantitatif, Kualitatif, dan R\&D. Bandung: Alfabeta.

Wahdatul, Laura, Sri Rahayu, dan Vaya Juliana Dillak. 2016. Pengaruh Anggaran Berbasis Kinerja dan Sistem Pelaporan Keuangan terhadap Akuntabilitas Kinerja Instansi Pemerintah https://openlibrary.telkomuniversity.ac.id/pustaka/116358/pengaruh-anggaran-berbasis- 
kinerja-dan-sistem-pelaporan-keuangan-terhadap-akuntabilitas-kinerja-instansipemerintah-kabupaten-bandung-.html/Diaksestanggal 10 Januari 2017. http://beritapagi.co.id/2016/05/18/sumsel-bertransformasi-jadi-provinsi-terbaik.html. Diakses tanggal 14 Mei 2017.

http://detiksumsel.com.html. Diakses tanggal 10 Maret 2017.

http://palembang.go.id.html. Diakses tanggal 10 Maret 2017.

http://wartasumsel.co.id/2016/12/22/pencapaian-pad-11-jenis-pajak-palembang-berhasilmelebihi-target.html. Diakses tanggal 14 Mei 2017.

http://www.rmolsumsel.com/read/2017/06/05/73241/Pegawai-Dinas-Perumahan-PalembangTerancam-Tak-Dapat-THR-.html. Diakses tanggal 23 Juni 2017.

http://palembang.tribunnews.com/2017/06/05/asn-kota-palembang-harap-harap-cemasbeberapa-skpd-terancam-tidak-terima-tpp-juni?page $=2$. html.

https://sumateradeadline.co.id/2017/03/20/minimalisir-kesalahan-laporan-daftar-hitamdiskominfo-bagikan-software-terbaru/. html.

http://www.nuansakita.com/peristiwa/bkpsdm-terapkan-laporan-keuangan-berbasisakrual/.htm 